\title{
Online reputation, virtual experience and tourists' revisit intentions. The case of Vilakazi street tourism corridor in Soweto
}

\begin{tabular}{|c|c|}
\hline \multicolumn{2}{|c|}{$\begin{array}{l}\text { Authors: } \\
\text { Freddy M. Mgiba }^{1} \\
\text { Norman Chiliya }^{10}\end{array}$} \\
\hline \multicolumn{2}{|c|}{$\begin{array}{l}\text { Affiliations: } \\
{ }^{1} \text { Department of Marketing, } \\
\text { Faculty of Economic and } \\
\text { Management Sciences, } \\
\text { University of the } \\
\text { Witwatersrand, } \\
\text { Johannesburg, South Africa }\end{array}$} \\
\hline \multicolumn{2}{|c|}{$\begin{array}{l}\text { Corresponding author: } \\
\text { Freddy Mgiba, } \\
\text { joycemgiba@webmail.co.za }\end{array}$} \\
\hline \multicolumn{2}{|c|}{$\begin{array}{l}\text { Dates: } \\
\text { Received: } 30 \text { Jan. } 2020 \\
\text { Accepted: } 28 \text { May } 2020 \\
\text { Published: } 25 \text { Aug. } 2020\end{array}$} \\
\hline \multicolumn{2}{|c|}{$\begin{array}{l}\text { How to cite this article: } \\
\text { Mgiba, F.M. \& Chiliya, N., } \\
\text { 2020, 'Online reputation, } \\
\text { virtual experience and } \\
\text { tourists' revisit intentions. } \\
\text { The case of Vilakazi street } \\
\text { tourism corridor in Soweto', } \\
\text { South African Journal of } \\
\text { Economic and Management } \\
\text { Sciences 23(1), a3533. } \\
\text { https://doi.org/10.4102/ } \\
\text { sajems.v23i1.3533 }\end{array}$} \\
\hline \multicolumn{2}{|c|}{$\begin{array}{l}\text { Copyright: } \\
\text { (C) 2020. The Authors } \\
\text { Licensee: AOSIS. This } \\
\text { is licensed under the } \\
\text { Creative Commons } \\
\text { Attribution License. }\end{array}$} \\
\hline \multicolumn{2}{|l|}{ Read online: } \\
\hline 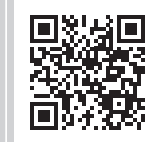 & $\begin{array}{l}\text { Scan this QR } \\
\text { code with your } \\
\text { smart phone or } \\
\text { mobile device } \\
\text { to read online. }\end{array}$ \\
\hline
\end{tabular}

Background: Academic literature has documented the benefits of technology for the tourism business. However, the influence of the fourth industrial revolution environment on the destination reputation, pre-visit experience, visit intentions and how these affect tourists' satisfaction and loyalty intentions have not received much attention, especially within the African context.

Aim: The purpose of this study was to empirically test the effect of this environment on all these variables.

Setting: This study is one of the few empirical types of research conducted in an urban tourism destination centre in a South African context.

Methods: The study employed a positivist quantitative research methodology. Primary data $(N=235)$ were collected from tourists who visited the Vilakazi Street precinct during October-November 2019, using the convenient probability sampling approach. For analysis, the study employed structural equation modelling.

Results: There are positive relationships between the fourth industrial revolution environment and the online reputation and the pre-visit experience. These, in turn, have a positive effect on the intention to visit the precinct, which affects the tourists' feelings of satisfaction after actually visiting the centre. Satisfaction has a positive impact on their loyalty intentions.

Conclusion: The findings create a space for future research by providing another framework for investigating the usefulness of new technology in the tourism industry, which can also extend to other industries. For managers, the findings can help in the creation of online advertisement strategies, online reputation management and online pre-visit experience enhancement.

Keywords: fourth industrial revolution; reputation; pre-visit experience; visit intention; satisfaction; loyalty.

\section{Introduction}

Tourism remains the main source of foreign exchange and a core industry for many countries (Watkins et al. 2018), and this includes South Africa (Pandy \& Rogerson 2018). This industry offers potential for innovation and the expansion of the economy (Biagi, Brandano \& Lambiri 2015; Nunkoo 2015). Recent developments have led to the conclusion that technological progress and tourism go hand in hand (Tussyadiah \& Sigala 2017), and that tourism markets shape and are shaped by technology (Benoit et al. 2018). New technology dictates the strategy and competitiveness of tourism organisations (Buhalis 2019), by providing unhindered access to consumers and tourism services, and by enhancing online transactions (Ukpabi \& Karjaluoto 2016). Presently, it is hard to decouple technology from tourism (Tussyadiah et al. 2017; Wang, Xiang \& Fesenmaier 2014). The fourth industrial revolution (4IR, an era characterised by high technological advancement) is therefore expected to cause dramatic changes in this sector in the coming years (Gül \& Gül 2018). Law, Buhalis, and Cobanoglu (2014) indicate that travellers with more information and communication technology (ICT) usage experience have greater repurchase intentions.

New technological innovations create new possible ways of interacting to which the industry needs to adapt (Gretzel \& Yoo 2013). They can dramatically affect the tourism industry (Watkins et al. 2018) by, among others, increasing the range of possible choices (Buhalis \& Law 2008; 
Inversini, Canfoni \& De Prieto 2014). For example: through online comments (Josang, Ismail \& Boyd 2007), a destination's reputation can be enhanced or destroyed (Komsic \& Dorcic 2014; Watkins et al. 2018). This would influence tourists' destination choices (Harvey \& Groutsis 2015), and their intentions to visit or revisit (Fu, Cai \& Lehto 2016; Kaplanidou \& Gibson 2010; Ledesma, Navarro \& Perez-Rofriguez 2005). In addition, digital technology can give customers a virtual experience of their potential destination, which can also affect their choices (Prasad \& Jha 2014). The ICT will increasingly reduce costs, allow easy access to information for customers and allow service providers to be in direct contact with consumers (Watkins et al. 2018). Due to the 4IR environment, consumers have now become 'prosumers' (producers + consumers), informed content generators and sources of feedback to organisations, key elements to understand and manage tourism businesses (Cid 2018). This relationship between tourism and technology can only grow exponentially, and the impact of the 4IR technology will be more severe on tourist centres' reputation, pre-visit experience and travellers' intention to visit (Kim et al. 2018). All these aspects affect tourists' satisfaction and loyalty intentions (Swanson \& Su 2017). From this introduction, it is clear that the 4IR is increasingly becoming more important to the tourism industry. This is, in part, due to its' potential to impact the online reputation of tourism destinations and to determine how people can virtually experience a tourist destination. The impact of the reputation and the pre-visit experience on the intention to visit an area, is well documented as will be shown below. What is not well established in literature is the extent to which the 4IR technologies affect a cultural tourist destination's reputation and the virtual experiencing of the destination, and how the combined effect of these two can lead to visitors' loyalty intentions.

In light of the increasing influence of 4IR technologies and the potential of the tourism industry, developing countries should should understand the development and implication of technologies in this industry and implement it more aggressively. The present study uses the Vilakazi Street precinct because of its characteristics and historic importance to the South African struggle.

Vilakazi Street is in a developing country, within a city with growing tourism (Rodegerson \& Rodegrson 2017), where most Johannesburg tourism takes place (Kgagudi 2019), and with a growing number of international visitors (Booyens 2010; Booyens \& Rogerson 2019; Rolfes, Steinbrink \& Uhl 2009). Tourists visit this precinct for its historic struggle attractions, such as the house of Nelson Mandela, the Hector Petersen Museum and Desmond Tutu's house (RodneyGumede 2019). In response to that, this precinct has been upgraded and expanded in a major way to include a vast array of shops, stalls and restaurants (Booyens \& Rogerson 2019). The Johannesburg Development Agency (JEDA) has also designated the precinct as a centre for heritage tourism (Rodney-Gumede 2019). In view of the above, gaps in knowledge and its historic nature, Vilakazi Street in Soweto provided an ideal setting for this study.

\section{Problem statement and purpose of the study}

Vargas-Sánchez, Plaza-Mejia and Porras-Bueno (2009) state that there is a lack of knowledge about the tourism business in developing countries in the new 4IR environment (Bahrin et al. 2016; Jones \& Pimdee 2017). Despite the increasing attention on investigating the relationships between technology and the tourism industry (see technology and tourism centres: Chen \& Huang 2017; technology and tourists experiences: Kharat et al. 2015; Prasad \& Jha 2014; technology and customers' behavioural intentions: Chen \& Petrick 2015; Kaplanidou \& Gibson 2010; Li \& Petrick 2010), there has not been an interest in empirically investigating the relationship between the 4IR environment and the tourism industry, with reference to destination area reputation, pre-visit and post-visit evaluation, customer experience and tourists' loyalty intentions. In consequence, there is a dearth of studies demonstrating these linkages in tourism literature (Shakouri, Yadzi \& Ghorchebigi 2019), and even more so for urban cultural tourist destinations areas (Vargas-Sánchez et al. 2009).

Secondly, numerous studies have shown the importance of the tourism industry in developing countries (Dissanayake, Asafu-Adjaye, \& Mahadeva 2017; Goffi, Cucculelli, \& Masiero, 2019. For instance, tourism is the principal export for many developing countries (Davison, Harris, Vogel \& Dixey 2005. However, there is also a lack of practical knowledge in the tourism business in these countries in the new environment (Bahrin et al. 2016; Jones \& Pimdee 2017). Despite the plethora of research on the impact of the 4IR on economies and tourism, to the authors' knowledge, there has not been any attempt to establish a generalisation about how the 4IR technologies impact the tourism industry, especially on cultural tourism centres like Vilakazi Street in Soweto. Given the importance of the 4IR and the tourism industry, and the dearth of literature dealing with international tourists' decision-making processes when choosing a cultural tourist destination and the lack of insight in doing business given the importance of these two, an attempt to quantitatively investigate how the 4IR impacts this industry is a worthwhile academic pursuit. The present study isolates the 4IR environment, online reputation, technology-enabled virtual experience of the Vilakazi Street precinct, the intention to visit, tourists' satisfaction and their loyalty intentions. This study contributes to knowledge by proposing and quantitatively testing a model that reveals the interrelatedness of these variables. This is important because it opens new avenues for further testing of these relationships in other cultural tourist centres. The study can also find application in management practice. Practitioners who would like to use targeted advertisements and promotions for international tourists can use the insight from this study to increase visitor numbers. The rest of the article follows this order: hypotheses development, the methodology of the study, data analysis, hypotheses test results and discussion, implications of the study, limitations of the study and references. 


\section{Hypothesis development}

This subsection attempts to show how the 4IR links with Vilakazi Street's online reputation and tourists' pre-visit virtual experiences, both of which impact tourists' intention to visit the precinct, their satisfaction level and their loyalty intentions.

\section{The 4IR and Vilakazi Street reputation}

The major distinguishing factors of the 4IR are rapid technological advances (Syam \& Sharma 2018), increased digitisation (Schwab 2016), and increased connectivity (Chukurna \& Konak 2018). It is fast reshaping a new business environment (Philbeck \& Davis 2018), and thus becoming a major economic issue (Delfmann et al. 2018; Tohanean \& Toma 2018). It is altering the competitive landscape by increasing the availability of substitute services (Schwab 2016). As an illustration, in the tourism industry, this era has increased the range of possible choices of destinations (Inversini, Cantoni \& De Prieto 2014; Komsic \& Dorcic 2016). For marketers, it has delivered tools to build better relationships with customers, and has led to social media marketing measures, which are a necessity to reach more customers effectively, reliably and efficiently (Chary 2014). It is also generally accepted that the 4IR affects customer expectations, customer perceptions, customers' intentions (Cervellon \& Galipienza 2015; Kwok \& Yu 2016; Lillqvist \& Louhiala-Salminen 2014) and, ultimately, affects their actual behaviour (Schwab 2016). Of interest to the present study, ICT has given rise to online destination reputation (Gössling, Hall \& Andersson 2016), which also influences people's choices (Harvey \& Groutsis 2015). This concept (firm's reputation) has received attention from marketing researchers (Petersen \& Lemke 2016; Vizcaíno-González, Iglesias-Antelo \& Romero-Castro 2019). For the tourism industry, destination reputation captures tourists' beliefs about the quality and features of a destination (Fu et al. 2016; Kock et al. 2019), affects customers' service choice, overall attitudes about services and trust, and influences their visit intentions (Duygun \& Mentes 2015). Destination reputation, therefore, has a big impact on tourists' destination choices, visiting experiences and perceived value (Fu et al. 2016). People share information about their experiences (Cantallops \& Salvi 2014; Chan \& Guillet 2011), and others refer to online reviews to obtain information on the quality of services provided by a tourism destination (Casalo et al. 2015; Zhu \& Zhang 2010). Observational learning theory teaches us that people's decisions are shaped by other people's experiences (Chen, Wang \& Xie 2011; Miklós-Thal \& Zhang 2013). Under the 4IR era, destination centres can develop both good and bad reputations without direct contact with customers. Tourists' generated content can confirm or refute the online reputation of tourist destinations (De Moya \& Jain 2013). In line with Harvey, Groutsis and Van Den Broek's (2018) classification, reputation for the present study will mean that of Vilakazi Street in Soweto, Johannesburg, in South Africa. Competitiveness and reputation mutually influence each other (Assaker et al. 2015; De Moya \& Jain 2013). Therefore,
ICT can affect the competitiveness of a destination by enhancing its online reputation:

H1: The 4IR has a positive effect on Vilakazi Street precinct's reputation.

\section{The fourth industrial revolution and Vilakazi Street tourists' pre-visit virtual experience}

When customers, directly or indirectly, encounter a brand (Alloza 2008; Brakus, Schmitt \& Zarantonello 2009), an experience that can affect their behaviour (Prasad \& Jha 2014) is bound to happen (Kumar, Dash \& Purwar 2013). It can, for instance, lead to positive word of mouth (WOM, Khan \& Rahman 2015), and to an increase in consumers' trust and willingness to use that brand (Dolbec \& Chebat 2013). These impressions and behavioural responses can become a tool to attain a competitive advantage (Clatworthy 2012). For that reason, marketers often attempt to influence them (Kharat \& Kharat 2017; Van Der Westhuizen 2018). In the 4IR environment, people can also encounter brands virtually (Pantano 2015). Digital technology can plunge people into a new world of real context (Guerra, Pinto \& Beato 2015). This 4IR-enabled virtual experience can generate emotions and social interactions (Guerra et al. 2015), and elicit the same reactions and emotions as those felt during a real experience (Garrozzino \& Bergamasco 2010). Today people can experience the content with higher vividness and realism (Bailey et al. 2015; Hsu, Tseng \& Kang 2018), which can stimulate a sense of presence in the real world, and thus facilitate the pre-purchase experience (Gül \& Gül 2018). Since services can also be experienced pre-consumption (Kharat \& Kharat 2017), impressions about them can also be formed pre-purchase (Ismail, 2010):

H2: There is a positive relationship between the $4 \mathrm{IR}$ and the pre-purchase experiences of Vilakazi Street visitors.

\section{Vilakazi Street's online reputation and tourists' intention to visit}

Behavioural intentions are intentions to visit or revisit Vilakazi Street, recommend Vilakazi Street to friends or others, and say positive things about it and the services it offers (Kiatkawsin \& Han 2017; Kim et al. 2018; Lo \& Wu 2014; Loureiro et al. 2013). The 4IR can act as both an inspiration and an enabler for tourists (Moeketsi 2019). Law, Buhalis and Cobanoglu (2014) state that travellers who use more information and communication technology have greater purchase intentions, and their online review and subjective experience could affect visits by other people to a destination (Assaker \& Mueller 2015). In that way, a destination's online reputation can influence tourists' future visit decisions, the intention to further spread positive e-WOM (Chen \& Petrick 2015; Li \& Petrick 2010), and, ultimately, enhance their loyalty (Chen \& Petrick 2015; Oliver 2010). Kim et al. (2018) affirm the same in stating that a destination's positive reputation has a positive effect on intentions to revisit. Studies have shown that there exists a significant relationship between the reputation of a tourism destination centre, tourists' decision-making 
(Altunel \& Kocak 2017; Suhartanto et al. 2018) and their behavioural intentions (such as initiating a visit or revisit) (Kaplanidou \& Gibson 2010; Oliver 2010). In addition, these intentions can be used as a predictor of future consumption behaviour (Jin, Lee \& Lee 2013; Kim 2018; Lai \& Chen 2011). Thus, in association with the literature cited above, this study posits the following hypothesis:

H3: The online reputation of Vilakazi Street in Soweto has a positive effect on tourists' intention to visit.

\section{Pre-visit virtual experience and intention to actually visit}

Future changes in the tourism market will be under the strong influence of new technologies (Petkovic, Pindzo \& Agic-Molnar 2018). This technology will increasingly play a significant role for both consumers and service providers (Gül \& Gül 2019; Opara \& Onyije 2013).

In the tourism industry, tourists' visit or purchase intention (PI) is the most vital aspect (Tsiotsou 2006), because it shows the probability, willingness and likelihood to visit an establishment (Rashid 2009), thus providing the best predictor of their planned behaviour (Al-Jubari, Hassan \& Linan 2018). It includes consumers' attitudes, and their motivations (Chaniotakis, Lymperopoulios \& Soureli 2010; Shah, Shahzd \& Ahmed 2012). Further, PI also offers the likelihood to engage in positive WOM, and a willingness to pay more for services (Hau et al. 2009; Zainor \& Mohd 2018). However, tourists' visit choices involve subjective judgment about destination areas (Blackwell, Miniard \& Engel 2001). Consumer behaviour studies show that tourists aim to maximise their utility by choosing an option that best meets their individual travel and vacation needs (Kock, Josiassen \& Assaf 2016; Prayag \& Ryan 2012). In the absence of real physical experience, the destination's online presence can influence their choices and visit intentions. Rodrigez-Diaz and Espino-Rodriguez (2018) state that recommendations by friends can be a good variable for perceived value. Tourists can vicariously assess the destination using technology (Fombrun 2012; Walker 2010). Online positive or negative messages about a tourism centre can be a proxy for judging their likely experience, should they visit the destination. Therefore, technology can determine tourists' mobility decisions:

H4: There is a positive relationship between the online virtual experience of Vilakazi Street and tourists' intention to visit the precinct.

\section{Intention to visit Vilakazi Street precinct and service satisfaction perception}

Satisfaction represents a positive consumer or tourist feeling towards a brand or a destination; therefore, from a psychological perspective, consumer or tourist engagement has a positive effect on satisfaction (Bryce et al. 2015; Zhou, Zhang \& Edelheim 2013). Moreover, loyalty represents the willingness of consumers or tourists to re-buy or revisit a brand product or destination consistently (So et al. 2016). Consumer or tourist engagement demonstrates deep

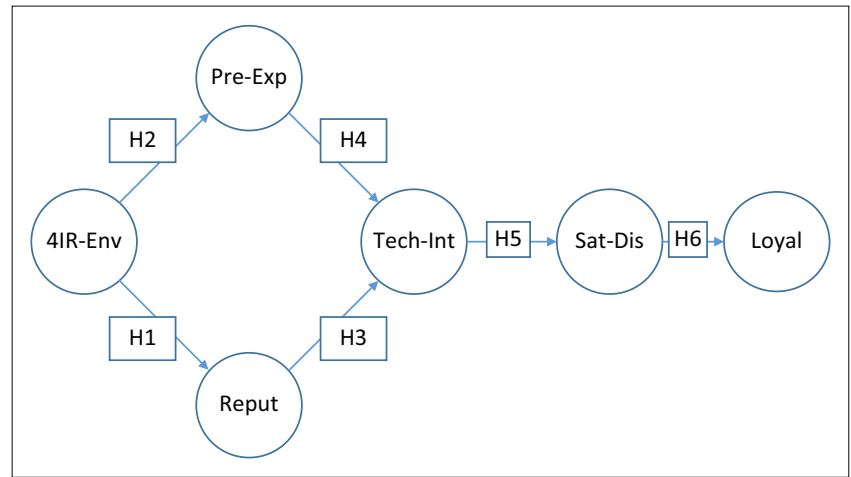

4IR-Env, fourth industrial revolution environment; Loyal, loyalty; Pre-Exp, customer pre-visit experience; Reput, reputation; Sat-Dis, perceived benefits or value or post-visit experience; Tech-Int, online-based intention to visit.

FIGURE 1: Proposed model.

commitment to and connection with the brand or destination, which can enhance the consumer or tourist's feelings and behaviours (Hollebeek 2011; So et al. 2014). An engaged tourist with a destination develops a more favourable attitude, and is, therefore, expected to be more interested to revisit and be more loyal towards a destination (Brodie et al. 2012). Understanding customer perceptions is crucial to attracting customers to purchase (Millar \& Baloglu 2008):

H5: There is a positive relationship between tourists' technologyenabled intention to visit and their satisfaction or dissatisfaction.

\section{Satisfaction perception and loyalty to Vilakazi Street precinct}

Customer satisfaction is the customers' service interactionrelated pleasurable response, based on a comparison of the service outcomes and a reference standard (Lechner \& Paul 2019; Oliver 2010). Customers' encounter with a service can either lead to satisfaction or dissatisfaction (Hulsheger \& Schewe 2011; Lechner \& Paul 2017). In turn, perceived satisfaction also influences purchase intention (Jaafar, Lalp \& Mohamed 2013). People who are dissatisfied with the service would be disloyal (Millar \& Baloglu 2008). Further, customer satisfaction has a positive effect on customer retention and profitability (Gupta \& Zeithaml 2006), which is also the strongest predictor of repeat purchases (Hussain 2017). Su et al. (2016) identify strong links between service quality, customer satisfaction and customer-company identification, which positively influences repurchase intention. It can, therefore, be concluded that service quality directly influences satisfaction (Han \& Hyun 2018) and behavioural intentions (Su et al. 2016). Consequently, this study hypothesises that:

H6: There is a positive relationship between customer experiences at Vilakazi Street and their loyalty intentions.

The hypotheses $(\mathrm{H} 1-\mathrm{H} 6)$ are represented in the form of a conceptual framework in Figure 1.

\section{Methodology}

The target population for the study was all guests to the Vilakazi Street precinct during the months of October and November 2019. The study followed a positivist approach and utilised the 
survey methodology for data collection. This approach is recommended for its efficiency (Moreira, Fortes \& Santiago 2017), objectivity and ease of generalisability (McCusker \& Gunaydin 2015). Due to the impossibility of obtaining a sampling frame, the authors followed a non-probability sampling method. Two trained field researchers assisted in the completion of the survey questionnaires by intercepting visitors at Vilakazi Street over the designated period.

\section{Measurement scale, data collection and ethical considerations}

The survey used originally designed questionnaires after an extensive literature review (Ashrafi \& Mueller 2015; Huang 2003). Measurement items were selected and context-adapted to suit the present study purpose and to ensure the validity and reliability of the measures. Six constructs were included, and all the survey questions measured these constructs. To minimise measurement errors, the researchers utilised multi-item measures for each construct (Churchill 1979). All scale items were scored on a five-point Likert scale ranging from 1 to 5 , with 1 = strongly disagree, 2 = disagree, 3 = neutral, $4=$ agree and $5=$ strongly agree. For the list of the constructs, operational definitions and the sources they were adapted from, see Table 1. Questionnaire development was in English, as participants were assumed to be English literate. The total number of items in the questionnaires was 37 (see addendum).

To minimise possible bias due to interviewer-participant interaction, participants were told that their partaking is voluntary and anonymous and they were encouraged to state their own personal opinion as truthfully as possible, in accordance with proper academic practice (Podsakoff et al. 2003). To mitigate the biasing effect of the research instrument, the questions asked were simple, specific and concise (Hulland, Baumgartner \& Smith 2018). Different variables measuring disparate items were separated across the survey (Tang et al. 2018). Further, the cover letter was structured in a way to make it appear that the measurement of the predictor variables is not related to outcome variables. The researchers also avoided the use of words with many meanings, in line with scholarly recommendations (Podsakoff et al. 2003). Throughout the project, the researchers maintained high standards of values and norms. They obtained permission from the major businesses in the area before data gathering could commence.
No data were collected to identify individual participants, and no incentives were offered that could possibly encourage their participation. Issues that might have affected the number of positive responses are the trust level between tourists and research assistants, the costs (in terms of time) and the nature of the research instrument (physical paper-based) (Koundinya et al. 2016). Also, there were no possibilities for using reminders to complete the questionnaires after contact sessions (Bosnjak et al. 2008; Saleh \& Bista 2017).

\section{Respondents' profile}

The target number of participants was 400. However, a sample size of 235 was achieved, representing a 59\% response rate. This sample size was deemed sufficient after taking into account the analysis method applied in the study. The number satisfies the recommended figure required for SmartPLS analysis purposes, and it provides more than sufficient (a minimum of 200) statistical power for analysis (Hoe 2008). Table 2 summarises the profile of the participants. The majority of participants were male, as evidenced by the $52.8 \%$ representation. From the table, it is clear that the people who visited the Vilakazi Street precinct were mostly the aged and highly educated individuals (about $50 \%$ of them with master's degrees). This has a bearing on how to target this segment and to tailor the advertisement messages. The income levels also show that the average visitor is a high net worth individual. Unfortunately, a large number of them preferred not to state their income levels. Many also chose not to state the amounts they spend on tourism.

\section{Data analysis}

This study applied partial least squares structural equation modelling (PLS-SEM) for data analysis, due to its numerous advantages over other approaches. The SEM approach can include latent constructs in the analysis while accounting for measurement errors in the estimation process (Ledermann \& Kenny 2017) and, most importantly, it provides support for examining and validating hypotheses of causal relationships due to its ability to do away with bias and distortion (Avkiran 2018; Naor \& Punj 2015). In particular, PLS-SEM is a more appropriate approach for complicated models or multigroup analysis than traditional SEM based on covariance

TABLE 1: Variables, operational definitions and sources.

\begin{tabular}{lll}
\hline Variable & Operational definition & Sources adapted from \\
\hline $\begin{array}{l}\text { Fourth industrial revolution } \\
\text { environment (4IR-Env) }\end{array}$ & $\begin{array}{l}\text { An era characterised by digitised technology, virtual experience, } \\
\text { online views. }\end{array}$ & $\begin{array}{l}\text { Chukurna and Konak 2018; Komsic and Dorcic 2016; Schwab 2016; } \\
\text { Syam and Sharma 2018. }\end{array}$ \\
$\begin{array}{l}\text { Reputation (Reput) } \\
\begin{array}{l}\text { Customer pre-visit experience } \\
\text { (Pre-Exp) }\end{array}\end{array}$ & $\begin{array}{l}\text { Pechnology-inspired virtual experience, positive electronic word } \\
\text { of mouth. }\end{array}$ & Gössling, Hay \& Anderson 2018 Harvey and Groutis 2015. \\
$\begin{array}{l}\text { Online-based intention to visit } \\
\text { (Tech-Int) }\end{array}$ & $\begin{array}{l}\text { Digital-technology-inspired (reputation and pre-visit experience) } \\
\text { likelihood to visit, for friends, after comparisons and persuasion. }\end{array}$ & Han et al. 2009. \\
$\begin{array}{l}\text { Perceived benefits or value or } \\
\text { post-visit experience (Sat-Dis) }\end{array}$ & $\begin{array}{l}\text { Value for money, enjoyment, meeting expectations, feeling of the } \\
\text { venue meeting expectations. }\end{array}$ & $\begin{array}{l}\text { Casalo et al. 2015; Fu et al. 2016; Khan \& Rahman 2015. } \\
\text { Hussain 2017. }\end{array}$ \\
$\begin{array}{l}\text { Loyalty (Loyal) } \\
\text { Future intentions to visit, spread good online reviews, and }\end{array}$ & Gupta and Zeithaml 2006; Jaafar et al. 2013. \\
\hline
\end{tabular}

Note: Please see the full reference list of the article, Mgiba, F.M. \& Chiliya, N., 2020, 'Online reputation, virtual experience and tourists' revisit intentions. The case of Vilakazi street tourism corridor in Soweto', South African Journal of Economic and Management Sciences 23(1), a3533. https://doi.org/10.4102/sajems.v23i1.3533, for more information. 
TABLE 2: Respondents' profiles.

\begin{tabular}{|c|c|c|}
\hline Description & Levels & $\%$ \\
\hline \multirow[t]{3}{*}{ Gender } & Male & 52.8 \\
\hline & Female & 45.5 \\
\hline & Prefer not to state & 1.7 \\
\hline \multirow[t]{4}{*}{ Age } & $<18$ years & 2.6 \\
\hline & $18-25$ years & 19.1 \\
\hline & $26-38$ years & 28.1 \\
\hline & $>39$ years & 48.9 \\
\hline \multirow[t]{5}{*}{ Educational level } & Below matric & 6.9 \\
\hline & Degree & 20.9 \\
\hline & Honours degree & 14.9 \\
\hline & Master's degree & 50.2 \\
\hline & PhD degree & 4.7 \\
\hline \multirow[t]{6}{*}{ Income level (Rand) } & $<500000$ & 4.3 \\
\hline & $500001-750000$ & 1.3 \\
\hline & $7500001-100000$ & 2.1 \\
\hline & $10000001-1250000$ & 6.0 \\
\hline & $>12500000$ & 29.8 \\
\hline & Prefer not to state & 56.6 \\
\hline \multirow[t]{7}{*}{ Expense level (Rand) } & $<1000$ & 6.4 \\
\hline & $1001-R 2000$ & 5.1 \\
\hline & 2001-R3000 & 2.1 \\
\hline & $3001-R 4000$ & 3.0 \\
\hline & 4001-R5000 & 3.4 \\
\hline & $>5000$ & 27.7 \\
\hline & Prefer not to state & 52.3 \\
\hline
\end{tabular}

(Hair et al. 2012). Smart PLS 3.2.6 was applied to analyse both the measurement and the structural models (Kim et al. 2018; Ringle, Wende \& Becker 2015), in accordance with Gerber's two-step approach (Zhaoa, Xub \& Wang 2019). Confirmatory factor analysis (CFA) and path analysis were performed simultaneously (Davari \& Rezazadeh 2015). Since CFA allows the researcher to test the hypothesis that a relationship exists between the observed variables and the underlying constructs (Suhr 2006), it, therefore, evaluates the measurement model's reliability and validity (how well the latent variables are measured by the observed variables) (Li et al. 2016). Path analysis is used to investigate the causal relationships among unobserved variables (Chin 1998; Mueser et al. 2017).

\section{The measurement model assessment}

The measurement model was first evaluated for reliability, convergent validity and discriminant validity as per scholarly recommendations (Ashrafi \& Mueller 2015). Cronbach's alpha coefficients and composite reliability (CR) values formed the basis for testing the reliability of the measurements. Diedenhofen and Musch (2016) state that Cronbach's alpha values greater than 0.6 are reliable. However, other researchers use 0.7 as a cut-off value (Cho, Hong \& Hyun 2009). All the Cronbach's alpha values exceeded the recommended higher threshold value of 0.7 (4IR-Env $=0.871$; Pre-Exp $=0.906$; Tech-Int $=0.875 ;$ Reput $=0.891 ;$ Sat-Dis $=$ 0.904; Loyal $=0.848)$. A CR index greater than 0.7 is deemed acceptable (Diedenhofen \& Musch 2016). From the results output, the lowest CR value was for loyalty (Loyal) with a value of 0.850 , while the highest $C R$ was for satisfaction (Sat-Dis) with 0.900 . High values for both Cronbach's alpha
TABLE 3: Cronbach's alpha, composite reliability and average extracted values.

\begin{tabular}{|c|c|c|c|}
\hline Variable & $\begin{array}{l}\text { Cronbach's } \\
\text { alpha }\end{array}$ & $\begin{array}{l}\text { Composite } \\
\text { reliability }\end{array}$ & $\begin{array}{c}\text { Average } \\
\text { variance } \\
\text { extracted }\end{array}$ \\
\hline $\begin{array}{l}\text { Fourth industrial revolution environment } \\
\text { (4IR-Env) }\end{array}$ & 0.871 & 0.887 & 0.540 \\
\hline Reputation (Reput) & 0.906 & 0.890 & 0.580 \\
\hline Customer pre-visit experience (Pre-Exp) & 0.891 & 0.890 & 0.580 \\
\hline Online-based intention to visit (Tech-Int) & 0.875 & 0.860 & 0.510 \\
\hline $\begin{array}{l}\text { Perceived benefits or value or post-visit } \\
\text { experience (Sat-Dis) }\end{array}$ & 0.904 & 0.900 & 0.610 \\
\hline Loyalty (Loyal) & 0.848 & 0.850 & 0.530 \\
\hline
\end{tabular}

TABLE 4: Inter-correlation matrix.

\begin{tabular}{lcccccc}
\hline Variable & 4IR-Env & Pre-Exp & Tech-Int & Reput & Sat-Dis & Loyal \\
\hline 4IR-Env & 1.000 & - & - & - & - & - \\
Pre-Exp & 0.850 & 1.000 & - & - & - & - \\
Tech-Int & 0.810 & 0.780 & 1.000 & - & - & - \\
Reput & 0.760 & 0.730 & 0.810 & 1.000 & - & - \\
Sat-Dis & 0.610 & 0.510 & 0.790 & 0.610 & 1.000 & - \\
Loyal & 0.760 & 0.690 & 0.860 & 0.820 & 0.800 & 1.000 \\
\hline
\end{tabular}

4IR-Env, fourth industrial revolution environment; Loyal, loyalty; Pre-Exp, customer pre-visit experience; Reput, reputation; Sat-Dis, perceived benefits or value or post-visit experience; Tech-Int, online-based intention to visit.

and CR (shown in Table 3) mean that all the measurement instruments used in the study are reliable.

Factor loadings generated with linear structural relations (LISREL) were also used to calculate the average variance extracted (AVE), the values used to check for convergent validity (Fornell \& Larcker 1981; Igbaria 1993). The AVE values are expected to be greater than the acceptable threshold of 0.5 (Hamouda \& Junoh 2018). In this model, the lowest AVE is 0.5673, which satisfies the limitation.

To check for discriminant validity, the researchers used the inter-construct correlation matrix as recommended (Chinomona \& Preterms 2011). Discriminant validity is proved when the value for correlation between variables is less than 1.0 (Hox et al. 2017). Table 4 indicates the inter-correction values for all the variables and they are all less than 1.0, hence confirming a good discriminant validity.

\section{Structural model: Model fit assessment}

After the reliability and validity checks of the measurement model, the next step was to assess the fit between the data and the proposed structural model. $R$-square values, $t$-values and factor loadings were used to assess the CFA model before using the model fit indices. According to Hair et al. (2017) $R$-square should be greater than $0.25, t$-statistics should be greater than 1.96 and the factor loadings should be greater than 0.5 . The structural model fitness was assessed using the Chi-square $\left(\chi^{2} / \mathrm{df}\right)$, the normed fit index, comparative fit index, incremental fit index, goodness of fit index, relative fit index and random measure of standard error approximation. Table 5 provides the acceptable threshold values, values for the model and the decisions after comparisons. All the model fit indicators met the acceptable threshold and the data were considered to fit the conceptualised model. 
TABLE 5: Goodness of fit table.

\begin{tabular}{lccc}
\hline Model fit indices & $\begin{array}{c}\text { Acceptable } \\
\text { threshold }\end{array}$ & $\begin{array}{c}\text { Current study } \\
\text { threshold }\end{array}$ & $\begin{array}{c}\text { Decision: acceptable } \\
\text { or unacceptable }\end{array}$ \\
\hline Chi-square value: $\chi^{2} /(d f)$ & $<3$ & 2.432 & Acceptable \\
Comparative fit index (CFI) & $>0.900$ & 0.970 & Acceptable \\
The goodness of fit index (GFI) & $>0.900$ & 0.740 & Acceptable \\
Incremental fit index (IFI) & $>0.900$ & 0.970 & Acceptable \\
Normed fit index (NFI) & $>0.900$ & 0.950 & Acceptable \\
Relative fit index (RFI) & $>0.900$ & 0.950 & Acceptable \\
$\begin{array}{l}\text { Random measure of standard } \\
\text { error approximation (RMSEA) }\end{array}$ & $<0.08$ & 0.080 & Acceptable \\
\hline
\end{tabular}

\section{Hypotheses testing results}

After model fit tests, the next step was to examine causal relationships among latent variables by path analysis (Hair et al. 2017; Henseler, Hubona \& Ray 2016; Lefcheck 2016).

Hypotheses are significant at a 95\% or higher level ( $\geq 95 \%)$ (Hair et al. 2010; Hastie, Tibshirani \& Friedman 2009). The $t$-statistics have to be greater than 1.96 for the proposed relationship to be acceptable. Table 6 gives a summary of the outcomes and shows the hypotheses, $t$-statistics, path coefficients and the decisions taken on whether to accept or reject the hypothesis (Shan et al. 2018). The path coefficients demonstrate the strength of the relationships between the dependent and the independent variables (Hsu 2008). Higher path coefficients indicate strong relationships among latent variables (Chinomona et al. 2010). The outcomes of the analysis demonstrated that all six hypotheses postulated were significant with the lowest $t$-statistical value being 5.480. For the complete list, see Table 6 .

\section{Results discussion and their implications}

All six the proposed hypotheses for the study are statistically significant. Individual path coefficients of $\mathrm{H} 1, \mathrm{H} 2, \mathrm{H} 3, \mathrm{H} 4$, H5 and H6 were 0.780, 0.870, 0.540, 0.400, 0.820 and 0.860 .

Individually, the outcomes of the hypotheses testing reveal the following:

- H1: The positive relationship between the 4IR and Vilakazi Street precinct's reputation reveals that the 4IR technology can actually lead people to experience the facilities before visiting. A positive reputation enhances the competitiveness of a destination and creates the demand for its services (Komsic \& Dorcic 2016).

- H2: The results confirmed that technology can help people to experience a service before the actual service is rendered and enjoyed. The 4IR can create a demand for tourism services by providing travel information to tourists, and thus provide the vicarious experience of the destination (Huang et al. 2016). Participants confirmed that their online exposure to Vilakazi Street made them want to visit. Rácz and Zilizi (2019) also confirm that, prior to a visit, tourists can experience a destination visually. Marasco et al. (2018) also concluded that online visual appeal has a positive significant effect
TABLE 6: Hypotheses, path coefficients, $t$-statistics and outcomes.

\begin{tabular}{lcccl}
\hline $\begin{array}{l}\text { Hypothesised } \\
\text { relationship }\end{array}$ & Hypotheses & $\begin{array}{c}\text { Path } \\
\text { coefficient }\end{array}$ & t-statistics & Outcome \\
\hline 4IR Env $\rightarrow$ Reput & H1 & 0.780 & 9.39 & $\begin{array}{l}\text { Significant and } \\
\text { supported }\end{array}$ \\
\hline 4IR-Env $\rightarrow$ Pre-Exp & H2 & 0870 & 9.940 & $\begin{array}{l}\text { Significant and } \\
\text { supported }\end{array}$ \\
Reput $\rightarrow$ Pre-Int & H3 & 0.540 & 6.640 & $\begin{array}{l}\text { Significant and } \\
\text { supported }\end{array}$ \\
Pre-Exp $\rightarrow$ Tech-Int & H4 & 0.400 & 5.480 & $\begin{array}{l}\text { Significant and } \\
\text { supported }\end{array}$ \\
Pre-Int $\rightarrow$ Sat-Dis & H5 & 0.820 & 8.110 & $\begin{array}{l}\text { Significant and } \\
\text { supported }\end{array}$ \\
\hline Sat-Dis $\rightarrow$ Loyal & H6 & 0.860 & 6.910 & $\begin{array}{l}\text { Significant and } \\
\text { supported }\end{array}$ \\
\hline
\end{tabular}

4IR-Env, fourth industrial revolution environment; Loyal, loyalty; Pre-Exp, customer pre-visit experience; Reput, reputation; Sat-Dis, perceived benefits or value or post-visit experience; Tech-Int, online-based intention to visit.

on behavioural intentions. However, the outcomes conflict with another study conducted in Spain (PerlesRibes et al. 2019a), which did not find any significant relationship between technology and the pre-visit experience of tourism centres. These various conclusions of this study warrant further investigation, especially with regard to the possible circumstances surrounding their settings.

- H3: The results confirmed a significant positive relationship between technology-aided pre-visit reputation and the intention to visit Vilakazi Street. Online consumers' interaction with the Vilakazi Street precinct can affect visit intentions (Law \& Ng 2016). This is in line with a recent study done on online reputation and its effect on people's behavioural intentions (Zhang et al. 2019).

- H4: The confirmation of the relationship between tourists' virtual experience and their resultant intention to visit confirms that online reviews can affect consumers' evaluation of services and their purchase intentions (Forougjhi et al. 2019; Liu et al. 2020).

- H5: The results confirmed the positive association between reputation and the virtual experience-inspired intention to visit and tourists' post-visit experience.

- H6: The outcome for this association confirmed that people who came to the precinct were generally satisfied with what they experienced and that the experience positively affected their loyalty intentions. Visitors to the precinct had a good experience and exhibited a commitment to revisit in the future (Yi \& La 2004) and preparedness to spread positive online recommendations (Forougjhi et al. 2019). The outcomes confirm, albeit in different contexts (Rasoolimanesh et al. 2019), several studies that investigated the consequences of tourist engagement, satisfaction and tourist loyalty (Bryce et al. 2015; Leckie, Nyadzayo \& Johnson 2016; So et al. 2016).

The 4IR technologies have fully immersed the tourism industry, and they are evolving all the time (Pencarelli 2019). From the hypotheses outcomes, it is clear that the future of the tourism industry, especially cultural tourism, lies in the strategic adoption of these technologies. They can be harnessed to maximise their positive impacts on this industry (Balasubramanian \& Rgavan 2019). 


\section{Implications of the study and its contribution to knowledge}

In this highly engaged and connected marketplace, tourists are increasingly turning to online communications to judge the quality of services before they visit. Since the tourism product is intangible and cannot be pretested by the potential tourist before purchase, technology makes it possible to have a sense of the experience (Ankomah \& Larson 2019). However, empirical studies demonstrating the linkages between technology and this industry are limited (Shakouri et al. 2017). As one of the first empirical studies on the use of technology in a developing country's urban tourism, we highlight the usefulness of technology in communicating with potential and actual visitors to destination centres. It, therefore, provides empirical evidence of the benefits of implementing 4IR technology in this industry (Gretzel \& Yoo 2013). For academics, it adds to the tools for understanding the role of new technology in enhancing the interface between tourists and service providers. The proposed framework is theory-driven and therefore advances future academic research work by tourism scholars. Academics can test the model in other contexts and in industries that exhibit similarities with the tourism industry, especially those that use ICT. It, therefore, contributes to the growing literature on services that entail the use of ICT. For management practitioners, the study provides strategic knowledge and actionable techniques to increase both the volume and profitability of tourists, and to lock out competition through technology. It also provides actionable guidance to managers concerned with online reputation management, online review solicitation and the combating of negative e-WOM. Further, organisations can use the results of this study to decide what information to display in their online advertisements and marketing. For Vilakazi Street businesses, it will help them to identify structural impediments to the full utilisation of their tourism assets and facilities. The policy implications of this study's findings would be relevant to other tourism centres in developing countries where historic considerations play an important role.

\section{Limitations of the study}

Our research raises several questions for future research to explore the centrality of novel technology in industries. Although the models and data utilised are rich and robust in many ways, our analysis does have its limitations. Like many others before us, this research used data from one destination centre, in one industry. As such, future investigations could very easily adapt the proposed framework to different contexts and conduct a cross-industry study on the effect of the 4IR technologies on customer loyalty. In addition, this study used self-reported questionnaires for data collection, and this can lead to biased regression coefficients (Antonakis et al. 2010). The other limiting factor of this study is the number of participants, which can render it ungeneralisable. Lastly, since the participants were people who visited the centre over a designated period, the possibilities of follow-up studies are much more limited.

\section{Acknowledgements Competing interests}

The authors have declared that no competing interest exists.

\section{Authors' contributions}

All authors contributed equally to this work.

\section{Ethical consideration}

Ethical clearance for the study was issued from the University of the Witwatersrand's ethics committee, HRECNM20-02-042, and the protocol number is $\mathrm{H} 20 / 03 / 14$.

\section{Funding information}

It is a self-funded project, no external funding requested.

\section{Data availability statement}

Data used in this article have been safely stored and can be used for further exploration.

\section{Disclaimer}

The study was conducted purely in pursuit of academic research by the researchers. No other interests featured.

\section{References}

Alloza, A., 2008, 'Brand engagement and brand experience at BBVA, the transformation of a 150 years old company', Corporate Reputation Review 11(1), 371-379. https://doi.org/10.1057/crr.2008.31

Al-Jubari, I., Hassan, A. \& Linan, F., 2019, 'Entrepreneurial intention among University students in Malaysia: Integrating self-determination theory and the theory of planned behavior', International Entrepreneurship and Management Journal 15(4), 1323-1342. https://doi.org/10.1007/s11365-018-0529-0

Altunel, M.C., \& Kocak, O.E., 2017, 'The role of subjective vitality, involvement, experience quality, and satisfaction tourists' behavioral intentions', European Journal of Tourism Research 16(1), 233-251.

Ankomah, P. \& Larson, T., 2018, 'Virtual tourism and its potential for tourism development in South-Saharan Africa' in M. Khrosrow-Pour (ed.), Encyclopedia of information science and technology, 4th edn., pp. 4113-4122, IGI Global, Hershey, PA.

Antonakis, J., Bendahan, S., Jacquart, P. \& Lalive, R., 2010, 'On making causal claims: A review and recommendations', The Leadership Quarterly 21(6), 1086-1120. https://doi.org/10.1016/j.leaqua.2010.10.010

Ashrafi, R. \& Mueller, J., 2015, 'Delineating IT resources and capabilities to obtain competitive advantage and improve firm performance', Information System Management 32(1), 5-38. https://doi.org/10.1080/10580530.2015.983016

Assaker, G., Hallak, R., Assaf, A.G. \& Assad, T., 2015, 'Validating a structural model of destination image, satisfaction, and loyalty across gender and age: Multigroup analysis with PLS-SEM', Tourism Analysis 20(6), 577-591. https://doi.org/10.3727 /108354215X14464845877797

Avkiran, N.K., 2018, 'An in-depth discussion and illustration of partial least squares structural equation modeling in health care', Health Care Management Science 21(3), 401-408. https://doi.org/10.1007/s10729-017-9393-7

Bahrin, M.A.K., Othman, M.F., Azli, N.N. \& Talib, M.F., 2016, 'Industry 4.0: A review on industrial automation and robotics', Jurnal Teknologi 78(6-13), 137-143. https://doi.org/10.11113/jt.v78.9285

Bailey, J.O., Bailenson, J.N., Flora, J, Armel, K.C. Voelker, D. \& Reeves, B., 2015, 'The impact of vivid and personal messages on reducing energy consumption related to hot water use', Environment and Behavior 20(10), 1-28. https://doi.org/ 10.1177/0013916514551604

Balasubramanian, K. \& Rgavan, N.A., 2019, 'What are the key challenges faced by the Malaysian hospitality and tourism industry in the context of industrial revolution 4.0?' Worldwide Hospitality and Tourism Themes 11(2), 194-203. https://doi.org/ 10.1108/WHATT-11-2018-0079

Benoit, K., Watanabe, K., Wang, H., Nulty, P., Obeng, A., Müller, S. \& Matsuo, A. 2018, 'quanteda: An R package for the quantitative analysis of textual data' The Journal of Open Source Software 3(30), 74. https://doi.org/10.21105/ joss.00774 
Biagi, B., Brandano, M.G. \& Lambiri, D., 2015, 'Does tourism affect house prices? Evidence from Italy', A Journal of Urban and Regional Policy 46(3), 351-528. https://doi.org/10.1111/grow.12094

Blackwell, R.D., Miniard, P.W. \& Engel, J.F., 2001, Consumer behavior, 9th edn., Harcourt College Publishers, Fort Worth, TX.

Booyens, I., 2010, 'Rethinking township tourism: Towards responsible tourism development in South African townships', Development Southern Africa 27(2), 273-287. https://doi.org/10.1080/03768351003740795

Booyens, I. \& Rogerson, C.M., 2019, 'Creative tourism: South African township explorations', Tourism Review 74(2), 256-267. https://doi.org/10.1108/TR-12 2017-0200

Bosnjak, M., Neubarth, W., Couper, M.P., Bandille, W. \& Kaczmire, L., 2008 'Prenotification in web-based access panel surveys - The influence of mobile tex messaging versus email on response rates and sample composition', Social Science Computer Review 26(2), 213-223. https://doi.org/10.1177/0894439307305895

Brakus, J., Schmitt, B. \& Zarantonello, L., 2009, 'Brand experience: What is it? How is it measured? Does it affect loyalty?' Journal of Marketing 73(3), 52-68. https://doi.org/10.1509/jmkg.73.3.052

Brodie, R.J., Hollebeek, L.D., Jurić, B. \& llić, A., 2011, 'Customer engagement: Conceptual domain, fundamental propositions, and implications for research', Journal of Service Research 14(3), 252-271. https://doi.org/10.1177/1094670511411703

Bryce, D., Curran, R., O'Gorman, K. \& Taheri, B., 2015, 'Visitors' engagement and authenticity: Japanese heritage consumption', Tourism Management 46(1), 571-581. https://doi.org/10.1016/j.tourman.2014.08.012

Buhalis, D., 2019, 'Technology in tourism-from information communication technologies to eTourism and smart tourism towards ambient intelligence tourism: A perspective article', Tourism Review 75(1), 267-272. https://doi.org/ 10.1108/TR-06-2019-0258

Buhalis, D. \& Law, R., 2008, 'Progress in information technology and tourism management: 20 years on and 10 years after the Internet: The state of eTourism research', Tourism Management 29(4), 609-623. https://doi.org/10.1016/j tourman.2008.01.005

Cantallops, A.S. \& Salvi, F., 2014, 'New consumer behavior: A review of research on eWOM and hotels', International Journal of Hospitality Management 36(1), 41-51. https://doi.org/10.1016/j.ijhm.2013.08.007

Casalo, L.V., Flavian, C., Guinaliu, M. \& Ekinci, Y., 2015, 'Avoiding the dark side of positive online consumer reviews: Enhancing reviews' usefulness for high riskaverse travelers', Journal of Business Research 68(9), 1829-1835. https://doi. org/10.1016/j.jbusres.2015.01.010

Cervellon, M.C. \& Galipienza, D., 2015, 'Facebook pages content, does it really matter? Consumers' responses to luxury hotel posts with emotional and informational content', Journal of Travel and Tourism Marketing 32(4), 428-437. https://doi.org /10.1080/10548408.2014.904260

Chan, N.L. \& Guillet, B.D., 2011, 'Investigation of social media marketing: How does the hotel industry in Hong Kong perform in marketing on social media websites?' Journal of Travel and Tourism Marketing 28(4), 345-368. https://doi.org/10.1080 /10548408.2011.571571

Chary, S.R.K., 2014, 'Social media marketing - the paradigm shift in internationa marketing', IOSR Journal of Business and Management 16(9), 11-13. https://doi.org/10.9790/487X-16921113

Chen, C.C. \& Petrick, J.F., 2015, 'The discriminant effect of perceived value on travel intention: Visitors versus non-visitors of Florida keys', Tourism Review International 19(3), 175-178. https://doi.org/10.3727/154427215X14430967453751

Chen, G. \& Huang, S., 2017, 'Toward a theory of backpacker personal development: Cross-cultural validation of the BPD scale', Tourism Management 59(1), 630-639. https://doi.org/10.1016/j.tourman.2016.09.017

Chen, Y., Wang, O. \& Xie, J., 2011, 'Online social interactions: A natural experiment on word of mouth versus observational learning', Journal of Marketing Research $48(2), 238-254$

Chin, W.W., 1998, 'The partial least squares approach to structural equation modeling', in G.A. Marcoulides (ed.), Modern methods for business research, pp. 295-358, Lawrence Erlbaum Associates, Mahwah, NJ.

Chinomona, R., Lin, J.Y.C., Wang, M.C.H. \& Cheng, J.M.S., 2010, 'Soft power and desirable relationship outcomes: The case of Zimbabwean distribution channels', Journal of African Business 11(2), 182-200. https://doi.org/10.1080/15228916.20 10.508997.

Chinomona, R., \& Preterms, M., 2011. SME manufacturers' cooperation and dependence on major dealers' expert power in distribution channels. South African Journal of Economic and Management Sciences, 14(2), 170-187.

Chaniotakis, I E, Lymperopoulios, C, \& Soureli, M., 2010, 'Consumers' intentions of buying own-label premium food products', Journal of Product and Brand management 19(5), 327-334.

Cho, K., Hong T., \& Hyun, C., 2009, 'Effect of project characteristics on project performance in construction projects based on structural equation model', Expert Systems with Applications 36(7), 10461-10470.

Chukurna, O.P. \& Konak, E.I., 2018, 'Evolution of the concept of digital marketing in the context of challenges in the fourth industrial revolution', Economics: Time Realities 1(35), 42-51.

Churchill, G.A., 1979, 'A paradigm for developing better measures of marketing constructs', Journal of Marketing Research 16(1), 64-73. https://doi.org/ $10.2307 / 3150876$

Cid, M.C., 2018, 'Collaborative quality: A new concept for tourism quality', Cuadernos de Turismo 42(1), 593-595.
Clatworthy, S., 2012, 'Bridging the gap between brand strategy and customer experience', Managing Service Quality: An International Journal 22(2), 108-127. experience, Managing Service Quality: An Intern
https://doi.org/10.1108/09604521211218936

Davari, A. \& Rezazadeh, A., 2015, 'The measurement of entrepreneurial outsourcing: Preliminary Scale development, dimensionality assessment, and construct validation', Journal of Technology Management \& Innovation 10(2), 211-224. https://doi.org/10.4067/S0718-27242015000200015.

Davison, R.M., Harris, R.W., Vogel, D.R., \& Dixey. L., 2005, 'E-commerce for communitybased tourism in developing countries', Proceedings of the 9th Pacific Asia Conference on Information Systems, -Bangkok, Thailand, 7-10 July (pp. 1396-1403).

De Moya, M. \& Jain, R., 2013, "When tourists are your "friends": Exploring the brand personality of Mexico and Brazil on Facebook', Public Relations Review 39(1) 23-29. https://doi.org/10.1016/j.pubrev.2012.09.004

Delfmann, W., Ten Hompel, M., Kersten, W., Schmidt, T. \& Stölzle, W., 2018, 'Logistics as a science: Central research questions in the era of the fourth industrial revolution', Logistics Research 11(23), 1-13. https://doi.org/10.23773/2018_9

Diedenhofen, B. \& Musch, J., 2016, 'cocron: A web interface and R package for the statistical comparison of Cronbach's Alpha coefficients', International Journal of Internet Science 11(1), 51-60.

Dissanayake, S., Asafu-Adjaye, J., \& Mahadeva., 2017, 'Addressing climate change cause and effect on land cover and land use in South Asia', Land Use Policy 67, 352-366.

Dolbec, P. \& Chebat, J., 2013, 'The impact of a flagship vs. a brand store on brand attitude, brand attachment, and brand equity', Journal of Retailing 89(4), 460-466. https://doi.org/10.1016/j.jretai.2013.06.003

Duygun, A. \& Mentes, S.A., 2015, 'The impacts of complaint satisfaction on corporate reputation, negative word-of-mouth communication intention, and repurchase intention', Balkan Journal of Social Sciences 4(8), 108-120.

Fombrun, C.J., 2012, 'The building blocks of corporate reputation: Definitions, antecedents, consequences', in M.L. Barnett \& T.G. Pollock (eds.), The Oxford handbook of corporate reputation, pp. 94-113, Oxford University Press, Oxford.

Fornell, C. \& Larcker, D.F., 1981, 'Evaluating structural equation models with unobservable variables and measurement error', Journal of Marketing Research 18(1), 39-50. https://doi.org/10.2307/3151312

Forougjhi, B., Iranmanesh, M., Gholipour, H.F. \& Hyun, S.S., 2019, 'Examining relationships among process quality, outcome quality, delight, satisfaction, and behavioural intentions in fitness centres in Malaysia', International Journal of behavioural intentions in fitness centres in Malaysia', International Journal of
Sports Marketing and Sponsorship 20(3), 374-389. https://doi.org/10.1108/ Sports Marketing a
IJSMS-08-2018-0078

Fu, X., Cai, L. \& Lehto, X., 2016, 'A Confucian analysis of Chinese tourists' motivations', Journal of Travel \& Tourism Marketing 32(3), 180-198. https://doi.org/10.1080/1 0548408.2014.896233

Fu, X., Cai, L., \& Lethto, X., 2017, 'Framing Chinese tourist motivations through the lenses of Confucianisim', Journal of Travel and Tourism Marketing, 34(2) 149-170. https://doi.org/10.1080/10548408.2016.1141156.

Garrozzino, M. \& Bergamasco, M., 2010, 'Beyond virtual museums: Experiencing immersive virtual reality in real museums', Journal of Cultural Heritage 11(4), 452-458. https://doi.org/10.1016/j.culher.2010.04.001.

Goffi, G., Cucculelli, M, Masiero, L., 2019, 'Fostering tourism destination competitiveness in developing countries: The role of sustainability', Journal of Cleaner Production 209, 101-115.

Gössling, S., Hall, C.M. \& Andersson, A.C., 2018, 'The manager's dilemma: A conceptualization of online review manipulation strategies', Current Issues in A conceptualization of online review manipulation strategies', Current Issues
Tourism 21(5), 484-503. https://doi.org/10.1080/13683500.2015.1127337

Gretzel, U. \& Yoo, K.H., 2013, 'Premises and promises of social media marketing in tourism', in S. McCabe (ed.), The Routledge handbook of tourism marketing, pp. 491-504, Routledge, New York, NY.

Guerra, J.P., Pinto, M.M. \& Beato, C., 2015, 'Virtual reality - Shows a new vision for tourism and heritage', European Scientific Journal 11(9), 49-54. https://doi.org/ 10.19044/esj.2015.v11n9p\%25p

Gül, M. \& Gül, K., 2018, 'The effect of the fourth industrial revolution on tourism', Economic Bulletin of the Ukrainian State Chemical-Technological University 2(8), 33-36. https://doi.org/10.32434/2415-3974-2018-8-2-33-39

Gül, K. \& Gül, K., 2019, 'Evaluation of ethnic cultural heritage in tourism: The case of Küçükköy Bosnian immigrants', Journal of Tourism and Gastronomy Studies 7(2), 1236-1351. https://doi.org/10.21325/JOTAGS.2019.418

Gupta, S. \& Zeithaml, V., 2006, 'Customer metrics and their impact on financial performance', Marketing Science 26(5), 551-765. https://doi.org/10.1287/ mksc.1060.0221

Hair, J.F., Black, W.C., Babin, B.J. \& Anderson, R.E., 2010, Multivariate data analysis, 7 th edn., Prentice-Hall, Upper Saddle River, NJ.

Hair, J.F., Sarstedt, M., Ringle, C.M. \& Godergan, S.P., 2017, 'Advanced issues in partial least squares structural equation modeling', Sage Publications, Los Angeles.

Hair, J.F., Sarstedt, M., Ringle, C.M. \& Mena, J.A., 2012, 'An assessment of the use of partial least squares structural equation modeling in marketing research', Journa of the Academy of Marketing Science 40(1), 414-433. https://doi.org/10.1007/ s11747-011-0261-6

Hamouda, Y.A.A., \& Junoh, M.Z.M., 2018, 'The role of corporate social responsibility to community on employees' job satisfaction and commitment to the organisation in construction corporates', International Journal of Innovative Science and Research Technology 3(12), 659-666.

Han, H., Hsu, L.T.J., Lee, J.S. \& Sheu, C., 2009, 'Are lodging customers ready to go green? An examination of attitudes, demographics, and eco-friendly
intentions', International Journal of Hospitality Management 30(2), 345-355. intentions', International Journal of Hospit
https://doi.org/10.1016/j.ijhm.2010.07.008 
Han, H. \& Hyun, S.S., 2018, 'Role of motivations for luxury cruise traveling, satisfaction, and involvement in building traveler loyalty', International Journal of Hospitality Management 70(1), 75-84. https://doi.org/10.1016/j.ijhm.2017.10.024

Harvey, W.S. \& Groutsis, D., 2015, 'Reputation and talent mobility in the Asia Pacific' Asia Pacific Journal of Human Resources 53(1), 22-40. https://doi.org/ 10.1111/1744-7941.12047

Harvey, W.S., Groutsis, D. \& Van Den Broek, D., 2018, 'Intermediaries and destination reputations: Explaining flows of skilled migration', Journal of Ethnic and Migration Studies 44(4), 644-662. https://doi.org/10.1080/1369183X.2017.1315518

Hastie, T., Tibshirani, R. \& Friedman, J., 2009, The elements of statistical learning: Dato mining, inference, and prediction, Springer, New York, NY

Henseler, J., Hubona, G. \& Ray, P.A., 2016, 'Using PLS path modeling in new technology research: Updated guidelines', Industrial Management \& Data Systems 116(1) research: Updated guidelines, Industrial Managem
2-20. https://doi.org/10.1108/IMDS-09-2015-0382

Hoe, S.L., 2008, 'Issues and procedures in adopting structural equation modeling techniques', Journal of Applied Quantitative Methods 3(1), 76-83.

Hollebeek, L., 2011, 'Exploring customer brand engagement: Definition and themes', Journal of Strategic Marketing 19(7), 555-573. https://doi.org/10.1080/096525 4X.2011.599493

Hox, J.J., Moerbeek, M. \& Van De Schoot, R., 2017, Multilevel analysis: Techniques and applications, 3rd ed., Taylor and Francis, Boca Raton, FL.

Hsu, S.H., 2008, 'Developing an index for online customer satisfaction: Adaptation of American Customer Satisfaction Index', Expert Systems with Applications 34, 3033-3042.

Hsu, W., Tseng, C. \& Kang, S., 2018, 'Using exaggerated feedback in a virtual reality environment to enhance behavior intention of water-conservation', Journal of Educational Technology \& Society 21(4), 187-203.

Huang, Y.C., Backman, K.F., Backman, S.J. \& Chang, L.L., 2016, 'Exploring the implications of virtual reality technology in tourism marketing: An integrated research framework', International Journal of Tourism Research 18(2), 116-128. https://doi.org/10.1002/jtr.2038

Huang, Z., 2003, Toward a deeper understanding of the adoption decision for interorganizational information systems (IOS): An investigation of Internet Edi (i-edi), Unpublished thesis, University of Memphis, Memphis, TN, viewed 21 July 2020, from https://dl.acm.org/doi/book/10.5555/959849.

Hulland, J., Baumgartner, H. \& Smith, K.M., 2018, 'Marketing survey research best practices: Evidence and recommendations from a review of JAMS articles', Journal of the Academy of Marketing Science 46(1), 92-108. https://doi.org/10.1007/ s11747-017-0532-y

Hulsheger, U.R. \& Schewe, A.F., 2011, 'On the costs and benefits of emotional labor: A meta-analysis of three decades of research', Journal of Occupational Health Psychology 16(3), 361-389. https://doi.org/10.1037/a0022876

Hussain, A., 2017, 'Transport infrastructural development and livelihood: A case of adaptation and diversification strategies in the face of tourism', paper presented at CAUTHE 2017: Time for big ideas? Rethinking the field for tomorrow, Dunedin, New Zealand, 7-10 February.

Igbaria, M., 1993, 'User acceptance of microcomputer technology: An empirical test', Omega 21(1), 73-90. https://doi.org/10.1016/0305-0483(93)90040-R

Inversini, A., Cantoni, L. \& De Prieto, M., 2014, 'Destination online communication: Why less is sometimes more. A study of online communications of English destinations', Journal of Travel \& Tourism Marketing 31(5), 563-575. https://doi.org/10.1080/10548408.2014.883949

Jaafar, S.N., Lalp, P.E. \& Mohamed, M., 2013, 'Consumers' perceptions, attitudes, and purchase intention towards private label food products in Malaysia', Asian Journal purchase intention towards private label food product
of Business and Management Sciences 2(8), 73-90.

Jin, N., Lee, H. \& Lee, S., 2013, 'Event quality, perceived value, destination image, and behavioral intention of sports events: The case of the IAAF World Championship Daegu, 2011', Asia Pacific Journal of Tourism Research 18(8), 849-864. https://doi.org/10.1080/10941665.2012.711336

Jones, C. \& Pimdee, P., 2017, 'Innovative ideas: Thailand 4.0 and the fourth industrial revolution', Asian International Journal of Social Sciences 17(1), 4-35. https://doi.org/10.25073/0866-773X/124

Josang, A., Ismail, R. \& Boyd, C., 2007, 'A survey of trust and reputation systems for online service provision', Decision Support Systems 43(2), 618-644. https://doi.org/10.1016/j.dss.2005.05.019

Kaplanidou, K. \& Gibson, H J., 2010, 'Predicting behavioral intentions of active event sport tourists: The case of a small-scale recurring sports event', Journal of Sport and Tourism 15(2), 163-179. https://doi.org/10.1080/14775085.2010.498261

Kgagudi, S.M., 2019, 'Soweto, The "storybook place": Tourism and feeling in a South African township', unpublished PhD dissertation, University of Pennsylvania, Philadelphia, PA, viewed 23 July 2020, from https://repository.upenn.edu/ Philadelphia, PA, vissertations/3320.
edis

Khan, I. \& Rahman, Z., 2015, 'A review and future directions of brand experience research', International Strategic Management Review 3(1-2), 1-14. https://doi.org/10.1016/j.ism.2015.09.003

Kharat, M.G., Chikhalkar, R.D., Jha, M.K. \& Kharat, M.G., 2015, 'Analyzing the antecedents and consequences of brand experience: An exploratory study in the case of consumer durables in the Indian context', International Journal of Marketing \& Business Communication 7(4), 12-31.

Kharat, M.G. \& Kharat, M.G., 2017, 'Revisiting brand experience: A research review, conceptual framework, and an agenda for future research', The Marketing Review 17(4), 469-493(25). https://doi.org/10.1362/146934717X15144729613915

Kiatkawsin, K. \& Han, H., 2017, 'Young travelers' intention to behave proenvironmentally: Merging the value-belief-norm theory and the expectancy theory', Tourism Management 59(1), 76-88. https://doi.org/10.1016/j.tourman 2016.06.018
Kim, J.H., 2018, 'The impact of memorable tourism experiences on loyalty behaviors: The mediating effects of destination image and satisfaction', Journal of Travel Research 57(7), 856-870. https://doi.org/10.1177/0047287517721369

Kim, M.J., Lee, C.K., Petrick, J.F. \& Hahn, S.S., 2018, 'Factors affecting international event visitors' behavioral intentions: The moderating role of attachment avoidance', Journal of Travel \& Tourism Marketing 35(4), 1027-1042. https://doi.org/10.1080/10548408.2018.1468855

Kock, F., Josiassen, A. \& Assaf, A.G., 2016, 'Advancing destination image: The destination content model', Annals of Tourism Research 61(1), 28-44. https://doi.org/10.1016/j.annals.2016.07.003

Kock, F., Josiassen, A., Assaf, A.G., Karpen, I. \& Farrelly, F., 2019, 'Tourism ethnocentrism and its effects on tourist and resident behavior', Journal of Travel Research 58(3) 427-439. https://doi.org/10.1177/0047287518755504

Komsic, J. \& Dorcic, J., 2016, 'Tourism destination competitiveness and online reputation: Conceptualization and literature framework analysis', in Tourism \& Hospitality Industry 2016, Congress Proceedings, pp. 144-157, Opatija, Croatia, 28-29 April.

Koundinya, V., Klink, J., Deming, P., Meyers, A. \& Erb, K., 2016, 'How do mode and timing of follow-up surveys affect evaluation success?', Journal of Extension 54(1), $1-10$.

Kumar, R.S., Dash, S. \& Purwar, P.C., 2013, 'The nature and antecedents of brand equity and its dimensions', Marketing Intelligence \& Planning 31(2), 141-159. equity and its dimensions', Marketing Intelliger
https://doi.org/0.1108/02634501311312044

Kwok, L. \& Yu, B., 2016, 'Taxonomy of Facebook messages in business-to-consumer communications: What really works?' Tourism and Hospitality Research 6(4), 311-328. https://doi.org/10.1177/1467358415600214

Lai, T.W. \& Chen, C.F., 2011, 'Behavioral intentions of public transition passengers: The roles of service quality, perceived value, satisfaction, and involvement', Transport Policy 18(2), 318-325. https://doi.org/10.1016/j.tranpol.2010.09.003

Law, M. \& Ng, M., 2016, 'Age and gender differences: Understanding mature online users with the online purchase intention model', Journal of Global Scholars of Marketing Science 26(3), 248-269. https://doi.org/10.1080/21639159.2016.11 74540

Law, R., Buhalis, D. \& Cobanoglu, C., 2014, 'Progress on information and communication technologies in hospitality and tourism', International Journal of Contemporary Hospitality Management 26(5), 727-750. https://doi.org/10.1108/IJCHM-082013-0367

Lechner, A.T. \& Paul, M., 2017, 'Is this smile for real? The role of affect and thinking style in customer perceptions of frontline employee emotion authenticity' Journal of Business Research 94(1), 195-208. https://doi.org/10.1016/j. jbusres.2017.06.009

Leckie, C., Nyadzayo, M.W. \& Johnson, L., 2016, 'Antecedents of consumer brand engagement and brand loyalty', Journal of Marketing Management 32(5-6), 558-578. https://doi.org/10.1080/0267257X.2015.1131735

Ledermann, T. \& Kenny, D.A., 2017, 'Analyzing dyadic data with multilevel modeling versus structural equation modeling: A tale of two methods', Journal of Family Psychology 31(4), 442-452. https://doi.org/10.1037/fam0000290

Ledesma, F.J., Navarro, M. \& Perez-Rodriguez, J.V., 2005, 'Return to tourist destination. Is it reputation, after all?' Applied Economics 37(18), 2055-2065. https://doi.org/ Is it reputation, after all?' Applied
$10.1080 / 00036840500293474$

Lechner, A.T. \& Paul, M., 2019, 'Is this smile for real? The role of affect and thinking style in customer perceptions of frontline employee emotion authenticity', Journal of Business Research 94(1), 195-208. https://doi.org/10.1016/j.jbusres.2017.06.009

Lefcheck, J.S., 2016, 'PiecewiseSEM: Piecewise structural equation modeling in R for ecology, evolution, and systematics', Methods in Ecology and Evolution 7(5), 573-579. https://doi.org/10.1111/2041-210X.12512

Li, P., Ryan, C. \& Cave, J., 2016, 'Chinese rural tourism development: Transition in the case of Qiyunshan, Anhui - 2008-2015', Tourism Management 55(1), 240-260. https://doi.org/10.1016/j.tourman.2016.02.007

Li, X. \& Petrick, J.F., 2010, 'Towards an integrative model of loyalty formation: The role of quality and value', Leisure Sciences 32(3), 201-221. https://doi.org/ 10.1080/01490401003709123

Lillqvist, E. \& Louhiala-Salminen, L., 2014, 'Facing Facebook: Impression management strategies in company-consumer interactions', Journal of Business and Technical Communication 28(1), 3-30. https://doi.org/10.1177/1050651913502359

Liu, Z., Lei, S.H., Guo, Y.L. \& Zhou, Z., 2020, 'The interaction effect of online review language style and product type on consumers' purchase intentions', Palgrave Communications, Palgrave Macmillan 6(1), 1-8. https://doi.org/10.1057/s41599020-0387-6

Lo, A.S. \& Wu, C., 2014, 'Effect of consumption emotion on hotel and resort spa experience', Journal of Travel \& Tourism Marketing 31(1), 958-984 https://doi.or $\mathrm{g} / 10.1080 / 10548408.2014 .895692$

Loureiro, S.M.C., Lopes, R., Kaufmann, H.R. \& Wright, L.T., 2013, 'How brand personality, brand identification, and service quality influence service brand equity', Cogent Business \& Management 1(1), 1-12. https://doi.org/10.1080/233 11975.2014.981329

Marasco, A., Buonincontri, P., Van Niekerk, M., Orlowski, M. \& Okumus, F., 2018 'Exploring the role of next-generation virtual technologies in destination marketing, Journal of Destination Marketing \& Management 9(1), 138-148. https://doi.org/10.1016/j.jdmm.2017.12.002

McCusker, K. \& Gunaydin, S., 2015, 'Research using qualitative, quantitative or mixed methods and choice based on the research', Perfusion 30(7), 537-542.

Miklós-Thal, J. \& Zhang, J., 2013, '(De)marketing to manage consumer quality inferences', Journal of Marketing Research 50(1), 55-69. https://doi.org/10.1509/
jmr.11.0432 
Millar, M. \& Baloglu, S., 2008, 'Hotel guests' preferences for Green Hotel attributes', Hospital Management, viewed 21 July 2020, from https://repository.usfca.edu.

Moeketsi, M., 2019, 'How the 4IR can propel Africa's rural tourism into the future', Daily Southern \& East African Tourism Updates, 21 August, 2019.

Moreira, A.C., Fortes, N. \& Santiago, R., 2017, 'Influence of sensory stimuli on brand experience, brand equity, and purchase intention', Journal of Business Economics and Management 18(1), 68-83. https://doi.org/10.3846/16111699. 2016.1252793

Mueser, K.T., Kim, M., Addington, J., McGurk, S.R., Pratt, S.I. \& Addington, D.E., 2017 'Confirmatory factor analysis of the quality of life scale and new proposed facto structure for the quality of life scale-revised', Schizophrenia Research 181(1), 117-123. https://doi.org/10.1016/j.schres.2016.10.018

Naor, J. \& Punj, G., 2015, 'Structural equation modeling of export behavior', in Developments in marketing science: Proceedings of the Academy of Marketing Developments in marketing
Science, Springer, Cham.

Nunkoo, R., 2015, 'Tourism development and trust in local government', Tourism Management 46(1), 623-634. https://doi.org/10.1016/j.tourman.2014.08.016

Oliver, R.L., 2010, Satisfaction: A behavioral perspective on the consumer, 2 nd edn. M.E. Sharpe, Armonk, NY

Opara, J.A. \& Onyije, L.E., 2013, 'Information and communication technologies (ICT): A Panacea to achieving effective goals in institutional administration', International Journal of Management Sciences 1(1), 11-15.

Pandy, W.R. \& Rogerson, C.M., 2018, 'Tourism and climate change: Stakeholder perceptions of at-risk tourism segments in South Africa', Euro Economica 37(2) 104-118.

Pantano, E., 2015, Successful technological integration for competitive advantage in retail settings, IGI Global, Hershey, PA.

Pencarelli, T., 2019, 'Tourism in Italy: The role of business networks for the revitalization of the sector' Information Technology \& Tourism, 1-22. https://doi.org/10.1007/ s40558-019-00160-3.

Perles-Ribes, J.F., Ramon-Rodríguez, A.B., Moreno-Izquierdo, L. \& Such-Devesa, M.J., 2019a, 'Online reputation and destination competitiveness: The case of Spain' Tourism Analysis 24(2), 161-176. https://doi.org/10.3727/10835421 9X15525055915518

Petersen, H.L. \& Lemke, F., 2015, 'Mitigating reputational risks in supply chains', Supply Chain Management: An International Journal 20(1), 495-510.

Petkovic, G., Pindzo, R. \& Agic-Molnar, M., 2018, 'Digital economy and (non) incremental changes in tourism and retail business model', Ekonomika Preduzeća 6(1-2), 151-165. https://doi.org/10.5937/EKOPRE1802151P

Philbeck, T. \& Davis, N., 2018, 'The fourth industrial revolution: Shaping a new era', Journal of International Affairs 72(1), 17-22.

Podsakoff, P.M., MacKenzie, S.B., Lee, J. \& Podsakoff, N.P., 2003, 'Common method biases in behavioral research: A critical review of the literature and recommended remedies', Journal of Applied Psychology 88(5), 879-903. https://doi.org/ 10.1037/0021-9010.88.5.879

Prasad, R.K. \& Jha, M.K., 2014, 'Consumer buying decision models: A descriptive study', International Journal of Innovation and Applied Studies 6(3), 335-351.

Prayag, G. \& Ryan, C., 2012, 'Antecedents of tourists' loyalty to Mauritius: The role and influence of destination image, place attachment, personal involvement, and satisfaction', Journal of Travel Research 51(3), 342-56. https://doi.org/10.1177/ 0047287511410321

Rácz, A. \& Zilizi, G., 2019, 'Virtual reality aided tourism', in Smart City Symposium Prague, pp. 23-24. https://doi.org/10.1109/SCSP.2019.8805727

Rashid N.A., 2009, 'Awareness of eco-label in Malaysia's green marketing initiative', International Journal of Business and Management 4(8), 132-141.

Rasoolimanesh, S.M., Md Noor, S. \& Schuberth, F, Jaafar, M., 2019, 'Investigating the effects of tourist engagement on satisfaction and loyalty', The Service Industries Journal 39(7-8), 559-574. https://doi.org/10.1080/02642069.2019.1570152

Ringle, C.M., Wende, S. \& Becker, J.M., 2015, Smart pls 3 (Computer software), viewed 23 July 2020, from http://smartpls.com.

Rodegerson, C.M. \& Rodegrson, J.M., 2017, 'City tourism in South Africa: Diversity and change', Tourism Review International 21(2), 193-211. https://doi.org/10.3727/1 54427217X14984977561745

Rodney-Gumede, Y., 2019, 'South Africa needs to think differently and embrace 4IR', Mail \& Guardian 09 March, 2019.

Rodrigez-Diaz, M. \& Espino-Rodriguez, F., 2018, 'A methodology for a comparative analysis of the lodging offer of tourism destinations based on online custome reviews', Journal of Destination Marketing \& Management 8(1), 147-160. https://doi.org/10.1016/j.jdmm.2017.02.006

Rolfes, M., Steinbrink, M. \& Uhl, C., 2009, 'Townships as an attraction: An empirical study of township tourism in Cape Town', Report by the University of Potsdam viewed 21 July 2020, from http://opus. kobv.de/ubp/volltexte/2009/2894/pdf/ viewed 21
pks46.pdf.

Saleh, A. \& Bista, K., 2017, 'Examining Factors Impacting Online Survey Response Rates in Educational Research: Perceptions of Graduate Students', Journal of Multidisciplinary Evaluation 13(29) 63-74.

Schwab, K., 2016, The fourth industrial revolution, World Economic Forum, Cologny.

Shah, S.I., Shahzd, A. \& Ahmed, T., 2012, 'Factors affecting Pakistan's university students' purchase intention toward foreign apparel brands', Management Journal of Contemporary Management Issues 12(3), 1-14. https://doi.org/ 10.1108/13612020810889263
Shakouri, B, Yazdi, S.K. \& Ghorchebigi, E., 2017, 'Does tourism development promote CO emissions?' Anatolia: An International Journal of Tourism and Hospitality $\mathrm{CO}_{2}$ emissions? Anatolia: An International Journal of Tourism and Hospitalit

Shan, S, Luo, Y, Zhou, Y. \& Wei, Y., 2018, 'Big data analysis adaptation and enterprises' competitive advantages: The perspective of dynamic capability and resourcebased theories', Technology Analysis \& Strategic Management 31(4), 406-420. https://doi.org/10.1080/09537325.2018.1516866

So, K.K.F., King, C., Sparks, B.A. \& Wang, Y., 2016, 'The role of customer engagement in building consumer loyalty to tourism brands', Journal of Travel Research 55(1), 64-78. https://doi.org/10.1177/0047287514541008

Su, M.M., Wall, G. \& Xu, K., 2016, 'Tourism-induced livelihood changes at Mount Sanqingshan World Heritage Site, China', Environmental Management 57(5), 1024-1040. https://doi.org/10.1007/s00267-016-0672-8

Suhartanto, D, Dean, D, Sosianika, A. \& Suhaeni, T., 2018, 'Food souvenirs and the influence on tourist satisfaction and behavioral intentions', European Journal of Tourism Research 18(1), 133-145.

Suhr, D.D., 2006, 'Exploratory or confirmatory factor analysis?' Statistics and Data Analysis 31, 1-17.

Swanson, S.R. \& Su, L, 2017, 'The effect of destination social responsibility on tourist environmentally responsible behavior: Compared analysis of first-time and repeat tourists', Tourism Management 60(1), 308-321. https://doi.org/10.1016/j. tourman.2016.12.011

Syam, N. \& Sharma, A., 2018, 'Waiting for a sales renaissance in the fourth industrial revolution: Machine learning and artificial intelligence in sales research and practice', Industrial Marketing Management 69(1), 135-146. https://doi.org/ 10.1016/j.indmarman.2017.12.019

Tang, M, Walsh, G, Lerner, D. \& Fitza, M.A., 2018, 'Green innovation, managerial concern, and firm performance: An empirical study', Business Strategy and the Environment 27(1), 39-51. https://doi.org/10.1002/bse.1981

Tohanean, D. \& Toma, S., 2018, 'Innovation, a key element of business models in the fourth industrial revolution', Romanian Foundation for Business Intelligence, Editorial Department VI(12), 121-130.

Tsiotsou, R., 2006, 'The role of perceived product quality and overall satisfaction on purchase intentions', International Journal of Consumer Studies 30(2), 207-217. https://doi.org/10.1111/j.1470-6431.2005.00477.x

Tussyadiah, I.P., Wang, D., Jung, T.H. \& Dieck, M.C.T., 2017, 'Virtual reality, presence, and attitude change: Empirical evidence from tourism', Tourism Management 66(1), 140-154. https://doi.org/10.1016/j.tourman.2017.12.003

Tussyadiah, I.P. \& Sigala, M., 2018, 'Shareable tourism: Tourism marketing in the sharing economy', Journal of Travel and Tourism Marketing 35(1), 1-4. https://doi.org/10.1080/10548408.2018.1410938

Ukpabi, D.C. \& Karjaluoto, H., 2016, 'The antecedents of consumer-generated media adoption for travel planning: A literature review', Proceedings of the 29th Bled eConference, University of Maribor, Bled, Slovenia.

Van Der Westhuizen, L., 2018, 'Brand loyalty: Exploring self-brand connection and brand experience', Journal of Product and Brand Management 27(4), 172-184. https://doi.org/10.1108/JPBM-07-2016-1281

Vargas-Sánchez, A, Plaza-Mejia, M. \& Porras-Bueno, N., 2009, ‘Understanding residents' attitudes toward the development of industrial tourism in a former mining community', Annals of Tourism Research 38(2), 460-480. https://doi.org/ 10.1177/0047287508322783

Vizcaíno-González, M., Iglesias-Antelo, S. \& Romero-Castro, N., 2019, 'Assessing sustainability-related systematic reputational risk through voting results in corporate meetings: A cross-industry analysis', MDPI, Open Access Journal 11(5), 1-11. https://doi.org/10.3390/su11051287

Walker, K., 2010, 'A systematic review of the corporate reputation literature: Definition, measurement, and theory', Corporate Reputation Review 12(4), 357-387. https://doi.org/10.1057/crr.2009.26

Wang, D., Xiang, Z. \& Fesenmaier, D.R., 2014, 'Adapting to the mobile world: A model of smartphone use', Annals of Tourism Research 48(1), 11-26. https://doi.org/ of smartphone use', Annals of
$10.1016 / j$.annals.2014.04.008

Watkins, M., Ziyadin, S., Imatayeva, A., Kurmangalieva, A. \& Blembayeva, A., 2018, 'Digital tourism as a key factor in the development of the economy', Economic Annals-XXI 169(1-2), 40-45. https://doi.org/10.21003/ea.V169-08

Yi, Y. \& La, S., 2004, 'What influences the relationship between customer satisfaction and repurchase intention? Investigating the effects of adjusted expectations and customer loyalty', Psychology and Marketing 21(5), 351-373. https://doi. org/10.1002/mar.20009

Zhang, T, Wang, W.Y.C., Cao, L. \& Wang, Y., 2019, 'The role of virtual try-on technology in online purchase decisions from consumers' aspects', Internet Research 29(3), 529-551. https://doi.org/10.1108/IntR-12-2017-0540

Zhaoa, Y, Xub, X. \& Wang, M., 2019, 'Predicting overall customer satisfaction: Big data evidence from hotel online textual reviews', International Journal of Hospitality Management 76(A), 111-121. https://doi.org/10.1016/j.ijhm.2018.03.017

Zhou, Q, Zhang, J.R. \& Edelheim, J., 2013, 'Rethinking traditional Chinese culture: A consumer-based model regarding the authenticity of the Chinese calligraphic landscape', Tourism Management 36(1), 99-112. https://doi.org/10.1016/j. tourman.2012.11.008

Zhu, F. \& Zhang, X., 2010, 'Impact of online consumer reviews on sales: The moderating role of product and consumer characteristics', Journal of Marketing 74(2), 133-148. https://doi.org/10.1509/jm.74.2.133 